\title{
Improvement of Hardness of Hydroxyapatite by the Addition of Silica from Tin Tailings
}

\author{
F Afriani $^{1 *}$, Evi.J ${ }^{1}$, Zaitun $^{2}$ and Y Tiandho ${ }^{1}$ \\ ${ }^{1}$ Department of Physics, Universitas Bangka Belitung, Kampus Terpadu UBB, Balunijuk, Kecamatan Merawang, \\ Kabupaten Bangka, Provinsi Kepulauan Bangka Belitung, Indonesia \\ ${ }^{2}$ Department of Precision Machinery and Precision Instrumentation,, University of Science and Technology of China, 443 \\ Huangshan Road, Hefei, Anhui, The People's Republic of China \\ *Email: fitri-afriani@ubb.ac.id
}

\author{
Article Information: \\ Received: \\ 4 October 2020 \\ Received in revised form: \\ 10 November 2020 \\ Accepted: \\ 5 December 2020
}

Volume 2, Issue 2, December 2020

pp. $85-89$

(C) Universitas Lampung

http://dx.doi.org/10.23960/jesr.v2i2.48

\begin{abstract}
The application of bone scaffolding in bone therapy is an alternative solution developed in bone tissue engineering technology to avoid bone donors' scarcity. The main requirement for a material that can be used as a scaffold is that it is biocompatible. Hydroxyapatite is a calcium phosphate ceramic that is often used as the primary material for scaffolding because it has good biocompatibility properties. However, like most ceramics, hydroxyapatite has low mechanical properties. In this study, we synthesized hydroxyapatite from cockleshell waste. To improve hydroxyapatite's mechanical properties (hardness), we added silica from tin tailings to hydroxyapatite. Through the analysis of the $x$-ray diffraction (XRD) pattern, it was found that hydroxyapatite was successfully synthesized from cockleshell using the co-precipitation method. Analysis of the diffraction pattern of tin tailings also shows that most of the crystals comprising tin tailings sand are silica in the $\alpha$-quartz phase. The addition of silica to hydroxyapatite followed by compaction and sintering at a temperature of $800^{\circ} \mathrm{C}$ did not produce a new crystal phase. The addition still has a diffraction pattern consisting of a combined XRD pattern of hydroxyapatite and silica. Based on the hardness test using the Vickers hardness method, it is known that the addition of silica can increase the hardness of hydroxyapatite.
\end{abstract}

Keywords: biomaterial, hydroxyapatite, silica, tailing.

\section{INTRODUCTION}

$\mathrm{I}_{\mathrm{N}}^{\mathrm{N}}$ $\mathrm{N}$ recent years, scientists in the field of bone tissue engineering have developed a scaffold that is applied to the bone therapy process to overcome the shortage of donors. It is hoped that the bone scaffold development can be an alternative to the bone therapy process [1], [2]. Conventional bone therapy methods such as allografts and autographs have several disadvantages, such as being prone to experiencing donor shortages, possible rejection, and viral infections [3].

One of the absolute conditions that must be met when a material is to be used as scaffolding is that the material must have good biocompatibility [4]. It is essential because the scaffolding will interact directly with human tissue when applied to the human body so that the use of materials with good biocompatibility will minimize the occurrence of side effects and accelerate the healing process. Hydroxyapatite is one material that is widely known to have good biocompatibility properties [5]. Hydroxyapatite is a bioceramic calcium phosphate family with the chemical formula $\mathrm{C}_{10}\left(\mathrm{PO}_{4}\right)_{6}(\mathrm{OH})_{2}$. The biocompatibility of hydroxyapatite is well understood because hydroxyapatite is the primary building block of human bones [6], [7].

One of the fascinating natural material sources to be synthesized into hydroxyapatite is cockleshells, especially Anadara granosa [8]. It is because the shells contain high amounts of calcium. Also, as an archipelago country, the production is abundant and can be obtained easily [9].

When applied to a porous scaffold, hydroxyapatite has drawbacks mainly related to its mechanical properties [10], [11]. Hydroxyapatite tends to be brittle, so it has mechanical properties that are feared not to bear the body's burden during the healing process. Whereas on the other hand, pores in the scaffold have an essential role, especially related to the transfer of nutrients to cells and space for cells to develop [12].

This article proposes an innovation to improve hydroxyapatite's mechanical properties, particularly 
hardness, by adding silica to hydroxyapatite. Silica is a material that is known to be used to improve the mechanical performance of a material [13], [14]. On the other hand, silica is a material that has good biocompatibility and can increase a scaffold's bioactivity [15], [16]. The source of silica to be applied comes from tin tailings sand silica. It is because the amount of tin tailings is abundant, considering that Indonesia is one of the primary tin producers in the world [17], [18].

\section{Materials AND METHODS}

To synthesize hydroxyapatite in this study, we used cockleshell waste from Pangkalpinang, Bangka Belitung Islands. The synthesis of hydroxyapatite was carried out by the co-precipitation method, as we have developed in the previous paper [19]. Before being used, the shell powder was calcined at a temperature of $1000^{\circ} \mathrm{C}$ to produce calcium oxide $(\mathrm{CaO})$. The calcium oxide powder was dissolved in distilled water and added with $\left(\mathrm{NH}_{4}\right)_{2} \mathrm{HPO}_{4}$ to have a $\mathrm{Ca} / \mathrm{P}$ ratio of 1.67 . The resulting precipitate was then sintered at a temperature of $900^{\circ} \mathrm{C}$. The silica used in this study is the silica of post-mining land in Pangkalpinang, Bangka Belitung Islands. After cleaning and refining, the silica is added to the hydroxyapatite by mixing it with distilled water media. The samples synthesized were hydroxyapatite without silica, hydroxyapatite with $20 \%$ by weight of silica (silica-20), and hydroxyapatite with $40 \%$ by weight of silica (silica-40). The mixing powder is compacted and sintered at a temperature of $800^{\circ} \mathrm{C}$. We use the x-ray diffraction (XRD) method to determine the crystal phase, while the hardness value was determined using Vickers hardness test.

\section{RESULTS AND DISCUSSIONS}

Figure 1 shows the XRD pattern of hydroxyapatite synthesized from cockleshells powder. It appears that almost all peaks in the $\mathrm{x}$-ray diffraction pattern correspond to the peaks belonging to the hydroxyapatite. Thus, it appears that this research has successfully synthesized hydroxyapatite from cockleshells. The hydroxyapatite produced has a hexagonal crystal system with a space group: $\mathrm{P} 63 / \mathrm{m}$. The lattice parameters of hydroxyapatite are: $a=b=$ $9,432 \AA$ and $c=6,881 \AA$. The XRD pattern of hydroxyapatite synthesized in this study is similar to the XRD pattern in Azis et al. (2018) with eggshells as the raw material [20].

In Figure 2, the XRD pattern of tin tailings is presented. It appears that through the analysis of the XRD pattern, it is known that the majority of tin tailing is composed of silica crystals. Most of the XRD peaks correspond to $\alpha$-quartz type silica (PDF-2: 01-0830539). Tin tailings silica has a hexagonal crystal system with space group $\mathrm{P} 3121$. The silica lattice parameters are $\mathrm{a}=\mathrm{b}=4,921 \AA$ and $\mathrm{c}=5,416 \AA$. This XRD analysis results follow the previously carried out XRF measurements, stating that the tin tailings contain high silica amounts, reaching $89.35 \%$ [21].

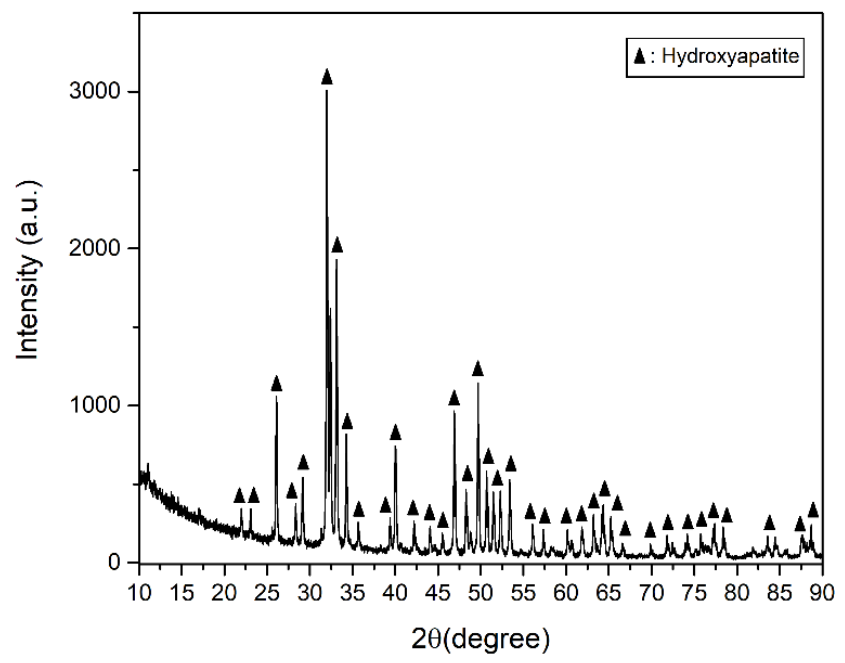

Figure 1. XRD pattern of hydroxyapatite

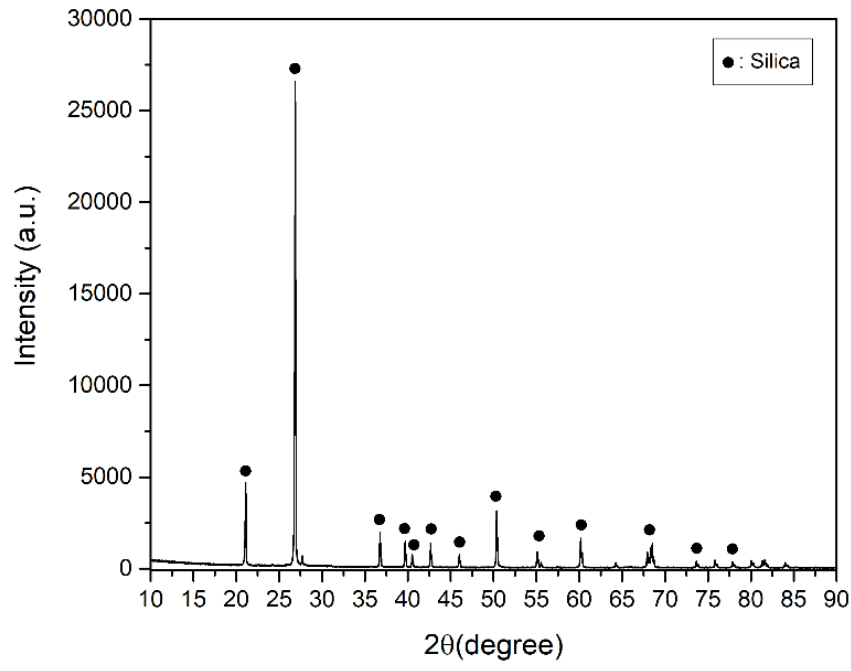

Figure 2. XRD pattern of silica tin tailings

The XRD pattern is obtained after adding silica to hydroxyapatite and continuing with the compaction and sintering process, as shown in Figure 3. It appears that the compaction process and the sintering process at a temperature of $800^{\circ} \mathrm{C}$ do not change the resulting hydroxyapatite phase. Based on the XRD pattern, it is known that the addition of silica to hydroxyapatite does not form a chemical reaction. The mixture between hydroxyapatite and silica is still composed of the two materials without any peaks forming associated with the impurity crystal phase. Therefore, this indicates that the synthesized mixture does not interfere with the two constituents' biocompatibility properties. The absence 
of a chemical reaction between hydroxyapatite and silica in this study is related to the low thermal energy given to the sintering process [22]. Also, the hydroxyapatite and silica phases in the quartz type have good stability.

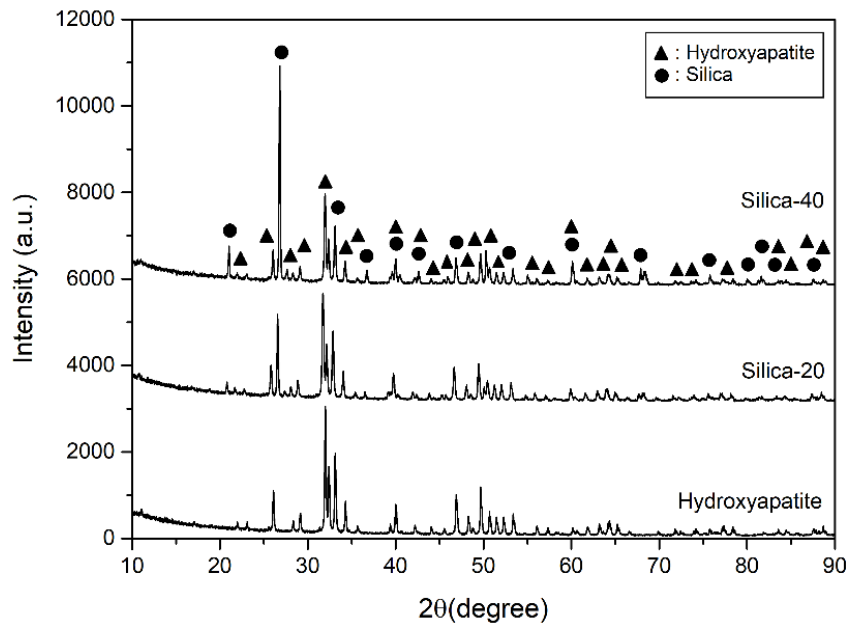

Figure 3. XRD pattern of the sample after adding silica to hydroxyapatite

In Figure 4, the results of hardness testing using the Vickers hardness method are presented. It appears that the indentation has a diamond shape. The indentation of hydroxyapatite without silica addition has a larger diagonal size compared to hydroxyapatite added with silica. It indicates that the addition of silica can increase the hardness of the hydroxyapatite mixture.

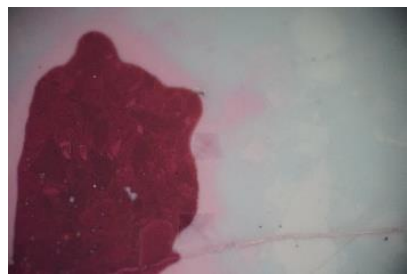

(a)

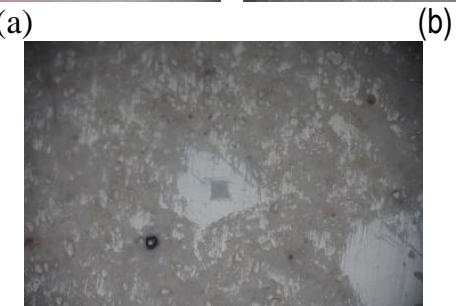

(C)

Figure 4. The results of the indentation micrograph: (a) hydroxyapatite without silica; (b) silica-20; and (c) silica-40

Quantitatively, the calculation of Vickers hardness (HV) is:

$$
H V=\frac{1.8544 F}{d^{2}}
$$

where $\mathrm{F}$ is the load applied, and $\mathrm{d}$ is the diagonal of the indentation. Using this formula, the hardness test results of the mixture of hydroxyapatite and silica synthesized in this study are shown in Table 1. Without the addition of silica, the hardness of the compacted and sintered hydroxyapatite is $32 \mathrm{HV}$. The addition of silica to hydroxyapatite will increase the hardness of $72 \mathrm{HV}$ for silica-20 and $54 \mathrm{HV}$ for silica-40. The increase in hardness due to silica in hydroxyapatite can be understood as an analogy with the appearance of the second phase in hydroxyapatite. This second phase can increase the stress in the material and is related to the hardness of the material. However, it appears the hardness of hydroxyapatite with the addition of $20 \%$ silica is higher than that of $40 \%$ addition of silica.

Table 1. Hardness testing results

\begin{tabular}{|c|c|}
\hline Silica percentage (wt $\%)$ & Hardness Vickers (HV) \\
\hline 0 & 32 \\
\hline 20 & 72 \\
\hline 40 & 54 \\
\hline
\end{tabular}

\section{Conclusions}

This study has succeeded in synthesizing hydroxyapatite with a hexagonal crystal structure from shells through the co-precipitation method. Based on $\mathrm{XRD}$ analysis, it is known that the composition of tin tailings sand is dominated by quartz silica. The addition of silica from tin tailings to hydroxyapatite followed by the compacting and sintering processes at a temperature of $800{ }^{\circ} \mathrm{C}$ did not produce new impurities. The XRD pattern resulting from the mixing still contains hydroxyapatite and silica compounds. Through the hardness test results, it appears that the addition of silica to hydroxyapatite is effective in increasing the hardness. Without silica addition, the hydroxyapatite's hardness was $32 \mathrm{HV}$, and after adding silica, the hardness reached $72 \mathrm{HV}$.

\section{ACKNOWLEDGMENT}

This research is supported by PDP grant, DIKTI Indonesia contract ID: 052/SP2H/LT/DRPM/2019.

\section{REFERENCES}

[1] F. Afriani, K. Dahlan, S. Nikmatin and O. Zuas, "Alginate affecting the characteristics of porous beta-TCP/alginate composite scaffolds. Journal of Optoelectronics and Biomedical Materials," Journal of Optoelectronics and Biomedical Materials, vol. 7, no. 3, pp. 67-76, 2015.

[2] T. Ghassemi, A. Shahroodi, M. Ebrahimzadeh, A. Mousavian, J. Movaffagh and A. Moradi, "Current concepts in scaffolding for bone tissue engineering," Archives of bone and joint surgery, vol. 6, no. 2, p. 90, 2018. 
[3] H. Haugen, S. Lyngstadaas, F. Rossi and G. Perale, " Bone grafts: which is the ideal biomaterial?," Journal of Clinical Periodontology, vol. 46, pp. 92-102, 2019.

[4] A. Przekora, "The summary of the most important cell-biomaterial interactions that need to be considered during in vitro biocompatibility testing of bone scaffolds for tissue engineering applications," Materials Science and Engineering: C, vol. 97, pp. 1036- 1051, 2019.

[5] F. Afriani, Siswoyo, R. Amelia, M. Hudatwi, Zaitun and Y. Tiandho, "Hydroxyapatite from natural sources: methods and its characteristics," IOP Conf. Series: Earh and Environmental Science, vol. 500, 2020.

[6] A. Szcześ., L. Hołysz and E. Chibowski, "Synthesis of hydroxyapatite for biomedical applications," Advances in Colloid and Interface Science, vol. 249, pp. 321 -330, 2017.

[7] P. Shi, M. Liu, F. Fan, C. W. L. Yu and M. Du., "Characterization of natural hydroxyapatite originated from fish bone and its biocompatibility with osteoblasts," Materials Science and Engineering: C, vol. 90, pp. 706-712, 2018.

[8] Y. Rizkayanti and Y. Yusuf, " Effect of temperature on syntesis of hydroxyapatite from cockle shells (Anadara granosa)," International Journal of Nanoelectronics and Materials, vol. 11, pp. 43-50, 2018.

[9] F. Afriani, Mustari and Y. Tiandho, "Pengaruh Lama Pemanasan Terhadap Karakteristik Kristal Kalsium dari Limbah Cangkang Kerang," Jurnal Pendidikan, Matematika, dan Sains, vol. 2, no. 2, pp. 189-200, 2018.

[10] J. Adhikari, M. S. Perwez, A. Das and P. Saha, "Development of hydroxyapatite reinforced alginate-chitosan based printable biomaterialink. Nano - Structures \& Nano -Objects," Nano Structures \& Nano-Objects, vol. 25, p. 100630, 2021.

[11] M. L. Qi, K. He, Z. N. Huang, R. ShahbazianYassar, G. Y. Xiao, Y. P. Lu and T. Shokuhfar, "Hydroxyapatite fibers: a review of synthesis methods," Jom, vol. 69, no. 8, pp. 1354- 1360, 2017.
[12] N. Abbasi, S. Hamlet, R. M. Love and N. T. Nguyen, "Porous scaffolds for bone regeneration," Journal of Science: Advanced Materials and Devices, vol. 5, no. 1, pp. 1-9, 2020.

[13] A. Megahed, M. Agwa and M. Megahed, "Improvement of hardness and wear resistance of glass fiber-reinforced epoxy composites by the incorporation of silica/carbon hybrid nanofillers," Polymer- Plastics Technology and Engineering, vol. 57, no. 4, pp. $251-259,2018$.

[14] O. Daramola and O. S. Akintayo, "Mechanical properties of epoxy matrix composites reinforced with green silica particles," Annals of the Faculty ofEngineering Hunedoara, vol. 15, no. 4, pp. 167$174,2017$.

[15] R. Eivazzadeh-Keihan, K. Chenab, R. TaheriLedari, J. Mosafer, S. Hashemi, A. Mokhtarzade, A. M. and M. Hamblin, "Recent advances in the application of mesoporous silica-based nanomaterials for bone tissue engineering," Materials Science and Engineering: C, vol. 107, p. $110267,2020$.

[16] N. Ituurioz-Rodiguez, M. A. Correa-Duarte and M. L. Fanarraga, "Controlled drug delivery systems for cancer based on mesoporous silica nanoparticles," International Journal of Nanomedicine, vol. 14, p. 3389, 2019.

[17] Y. Tiandho, H. Aldila, Mustari, Megiyo and F. Afriani, " Utilization of wasted cockle shell as a natural coagulant and a neutralizer of polluted water in Bangka Belitung islands, Indonesia.," Journal of Physics: Conference Series, vol. 1013, p. 012181, 2018.

[18] J. Evi, Y. Tiandho, R. A. Rafsanjani and F. Afriani, "Purification of silica from tin tailings through solid- state method," IOP Conference Series: Earth and Environmental Science, vol. 353, p. 012025, 2019.

[19] F. Afriani, Y. Tiandho, J. Evi and R. Rafsanjani, " Synthesis and characterization of hydroxyapatite/silica composites based on cockle shells waste and tin tailings," IOP Conference Series: Earth and Environmental Science, vol. 353, p. 012032, 2019. 
[20] Y. Azis, M. Adrian, C. D. Alfarisi, Khairat and R. M. Sri., " Synthesis of hydroxyapatite nanoparticles from egg shells by sol-gel method," IOP Conference Series: Materials Science and Engineering, vol. 345, p. 012040, 2018.

[21] F. Afriani, J. Evi, R. Mahardika, R. Rafsanjani and Y. Tiandho, " Purification of silica from tin tailing by acid leaching methods," Advances in Engineering Research, vol. 167, pp. 5-7, 2019.
[22] V. Rodriguez-Lugo, T. V. K. Karthik, D. Mendoza-Anaya, E. Rubio-Rosas, L. S. Villasenor-Ceron, M. I. .. Reyes-Valderrama and E. Sallinas-Rodiguez, "Wet chemical synthesis of nanocrystalline hydroxyapatite flakes: Effect of $\mathrm{pH}$ and sintering temperature on structural morphological properties," Royal Society Open Science, vol. 5, no. 8, p. 180962, 2018. 